\title{
A new syndrome mimicking Jaffe-Campanacci syndrome: a case report
}

\author{
Jaffe-Campanacci sendromunu taklit eden yeni bir sendrom: Olgu sunumu \\ Adnan Sevencan, M.D., Ulukan İnan, M.D., Nusret Köse, M.D. \\ Department of Orthopedics and Traumatology, Medical Faculty of Eskişehir Osmangazi University, Eskişehir, Turkey
}

\begin{abstract}
Jaffe-Campanacci syndrome (JCS) is a well-known condition with its clinical and radiological characteristics. Extraskeletal congenital anomalies of this syndrome include café-au-lait spots, mental retardation, cardiovascular abnormalities, ocular deformities, hypogonadism or cryptorchidism. Multiple non-ossifying fibromas are also characteristic bone lesions. In this article, we present a new syndrome mimicking JCS, which is characterized by a simple bone cyst and extraskeletal lesions.

Key words: Abnormality; café-au-lait spots; Jaffe-Campanacci syndrome; neurofibromatosis; non-ossifying fibroma; simple bone cyst; skeleton.
\end{abstract}

Campanacci et al. ${ }^{[1]}$ in 1983 reported the first complete description of clinical aspects and radiographic evidence for a new syndrome distinguished by multiple non-ossifying fibromas (NOF) of the bones associated with extraskeletal congenital anomalies such as café-au-lait spots, mental retardation, cardiovascular malformations, ocular anomalies, hypogonadism or cryptorchidism. Prior to Campanacci et al., ${ }^{[1]} \mathrm{Jaffe}^{[2]}$ was the first to notice the novel entity and distinguish it from fibrous dysplasia and neurofibromatosis. In short, the connection of multiple non-ossifying fibromas with café-au-lait skin patches has been named the Jaffee-Campanacci syndrome (JCS). Patients afflicted with this syndrome usually have no family history of comparable tribulations. The basis for the disease is unknown but it is presumed that there is an underlying aberration on the patient's chromosomes. There are still limited numbers of case reports regarding the existence of JCS; we therefore aimed to present a new syndrome mimicking JCS or a possible variant form of
Jaffe-Campanacci sendromu (JCS) klinik ve radyolojik özellikleri ile detaylı olarak bilinmektedir. Bu sendrom için iskelet dışı doğuştan anomaliler; café-au-lait lekeleri, mental gerilik, kalp-damar anomalileri, göz bozuklukları, hipogonadizm veya kriptorşizm görülebilecek özelliklerdir. Çoklu non-ossifiye fibromlar da karakteristik kemik lezyonudur. Bu yazıda JCS'yi taklit eden basit kemik kisti ve iskelet sistemi dışı lezyonları ile karakterize yeni bir sendrom sunuldu.

Anahtar sözcükler: Anomali; café-au-lait lekeleri; Jaffe-Campanacci sendromu; nörofibromatozis; non-ossifiye fibrom; basit kemik kisti; iskelet.

JCS without non-ossifying fibromas but with a simple bone cyst and extraskeletal anomalies which have not been previously described.

\section{CASE REPORT}

A 10-year-old boy was admitted to the department of orthopedic surgery with the complaints of pain and swelling of the proximal part of his left humerus. Our attention was attracted by the appearance of the patient since he showed the unusual clinical findings of growth retardation, mild mental retardation, pulmonary stenosis, spina bifida, ocular anomaly, right cryptorchidism and left hydrocele, erythema, and alopecia areata.

Furthermore, he was the first boy of a healthy family with a normal younger brother. The genetic examination, family pedigree, details of pregnancy, delivery and the postnatal period were all normal. Detailed medical history revealed that the child

- Received: July 12, 2012 Accepted: November 08, 2012

- Correspondence: Adnan Sevencan, M.D. Eskișehir Osmangazi Üniversitesi Tıp Fakültesi Ortopedi ve Travmatoloji Anabilim Dalı, 26480 Meselik, Eskisehir, Turkey. Tel: +90 505 - 9292686 Fax: +90 222 - 2397691 e-mail: adnansevencan@hotmail.com

- Presented at the XXII Turkish National Congress of Orthopaedics and Trauma Association, October 31-November 5, 2011, Antalya, Turkey. 
was normal at birth but was diagnosed with growth retardation at age three and that his weight was persistently below the third percentile for his age group. The clinical findings demonstrated that the bone age of the child was four when he was actually 6.5 years old. Mild mental retardation manifested during the developmental period. In addition to having erythema and hair loss from the eyebrows and alopecia areata, he was diagnosed with pulmonary stenosis, spina bifida, cryptorchidism on the right side and a hydrocele on the left side at age five. He also had an operation for the cataract in the left eye at age nine. Last year he had a probable pathologic fracture of the proximal humerus which was treated conservatively at that time.

On complete physical examination, the patient showed small stature (height: $110 \mathrm{~cm}$ and weight: $20 \mathrm{~kg}$, both below the third percentile). He did not have cutaneous lesions but there were erythema and hair loss from his eyebrows (Figure 1). Radiographic examination of the entire skeleton revealed a lesion in the proximal part of the left humerus characterized by central osteolysis which mildly expanded the cortex as single bony septa. The lesion depicted well-defined borders with no osteosclerotic rim (Figure 2). No other skeletal lesions were present and all routine biochemical tests were normal as well. During the operation the diagnosis of a simple bone cyst or unicameral bone cyst was confirmed with aspiration of clear fluid from the cyst. Curettage and bone grafting of the simple bone cyst were performed and histological examination established a definitive diagnosis of simple bone cyst with bands of fibroblastic tissue lining the cyst (Figure 3).

\section{DISCUSSION}

Jaffe-Campanacci syndrome is a very rare but distinct entity with constant features of multiple nonossifying fibromas in association with extraskeletal congenital anomalies. Until now 20 cases (6 girls, 14 boys), ranging in age from 4-18 years, have been published ( 1 case by Mirra et al., ${ }^{[3]} 10$ cases by Campanacci et al., ${ }^{[1]} 1$ case by Steinmetz et al., ${ }^{[4]} 1$ case by Kotzot et al., ${ }^{[5]} 1$ case by Boivin et al., ${ }^{[6]} 1$ case by Hau et al., ${ }^{[7]} 4$ cases by Colby and Saul, ${ }^{[8]}$ and 1 case by Al-Rikabi et al. $\left.{ }^{[9]}\right)$. Originally described extraskeletal anomalies included café-au-lait spots, mental retardation, urogenital anomalies, ocular anomalies, cardiovascular malformations, kyphoscoliosis, and precocious puberty. Other anomalies were also reported later such as chylothorax, chylopericardium, ptosis, sternal depression, and toe anomalies (Kotzot et al., ${ }^{[5]}$ and Boivin et al. ${ }^{[6]}$ ). Growth retardation, spina bifida, erythema and hair loss from the eyebrows as in our case have not been described in any patient until now.

The accurate incidence of this syndrome is probably underestimated because of unrecognized features.

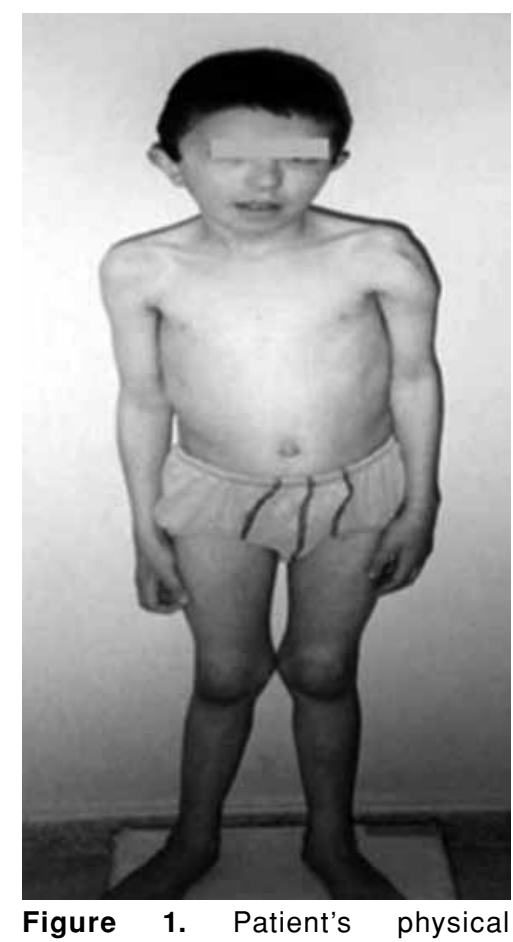

appearance with small stature.

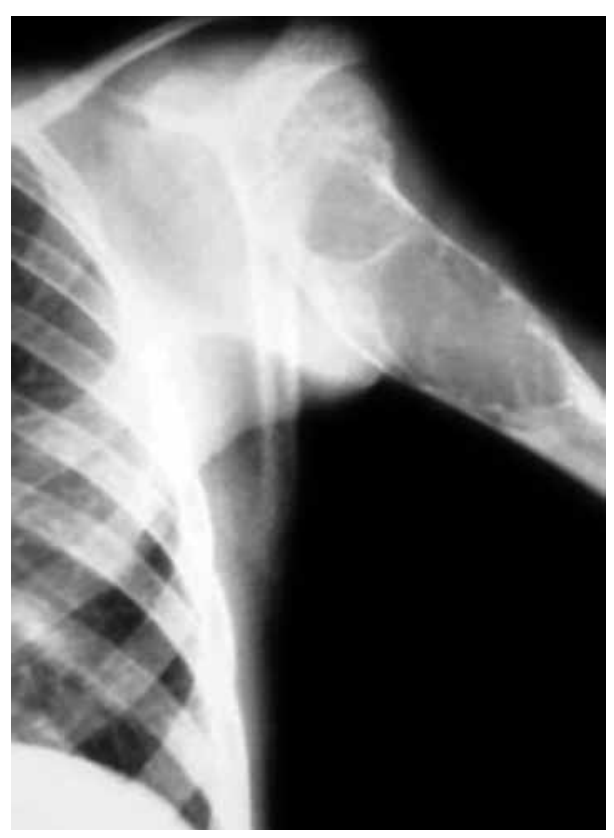

Figure 2. Simple bone cyst of the left proximal humerus characterized with central osteolysis and single bony septa. No osteosclerotic rim was present. 


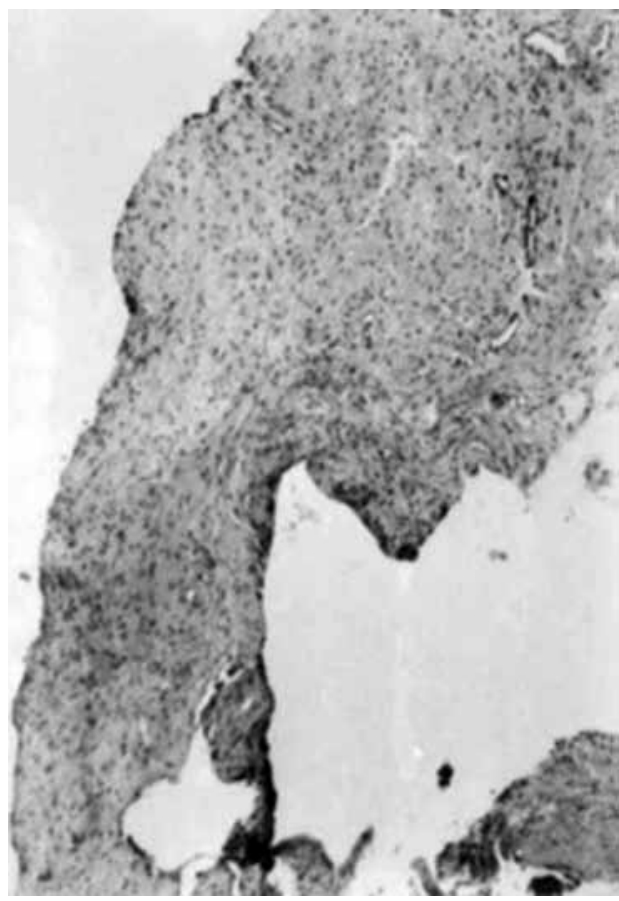

Figure 3. Bands of fibroblastic tissue which lining the simple bone cyst ( $\mathrm{H}-\mathrm{E} \times 40)$.

A high incidence of extraskeletal congenital anomalies emphasizing that all patients with JCS should be thoroughly investigated. Notevery feature of a syndrome necessarily has to be present in every case. As in most syndromes, a single feature is not pathognomonic for a JCS. The presence of the different radiographic pictures, the distribution of the skeletal lesions, and non-ossifying fibromas are constantly characteristic for the disease but extraskeletal anomalies may vary. The number of extraskeletal anomalies ranged from one to five. However, in the literature no patient having all the extraskeletal anomalies has been described.

This case has a simple bone cyst which is common in childhood ${ }^{[10]}$ and middle ages, ${ }^{[1]}$ as a main skeletal lesion unlike JCS which has M-NOF in addition to extraskeletal findings like growth retardation, spina bifida, erythema and hair loss on eyebrows and alopecia areata. Therefore, this case can be proposed as a new syndrome.

\section{Declaration of conflicting interests}

The authors declared no conflicts of interest with respect to the authorship and/or publication of this article.

\section{Funding}

The authors received no financial support for the research and/or authorship of this article.

\section{REFERENCES}

1. Campanacci M, Laus M, Boriani S. Multiple non-ossifying fibromata with extraskeletal anomalies: a new syndrome? J Bone Joint Surg [Br] 1983;65:627-32.

2. Jaffe HL. Tumors and tumorous conditions of the bones and joints. London: Henry Kimpton; 1958. p. 83-91.

3. Mirra JM, Gold RH, Rand F. Disseminated nonossifying fibromas in association with café-au-lait spots (JaffeCampanacci syndrome). Clin Orthop Relat Res 1982;168:192-205.

4. Steinmetz JC, Pilon VA, Lee JK. Jaffe-Campanacci syndrome. J Pediatr Orthop 1988;8:602-4.

5. Kotzot D, Stöss H, Wagner H, Ulmer R. Jaffe-Campanacci syndrome: case report and review of literature. Clin Dysmorphol 1994;3:328-34.

6. Boivin C, Kerbrat JB, Michot C, Peron JM, Hemet J. JaffeCampanacci syndrome. Report of a case. Ann Pathol 1994;14:108-11.

7. Hau MA, Fox EJ, Cates JM, Brigman BE, Mankin HJ. JaffeCampanacci syndrome. A case report and review of the literature. J Bone Joint Surg [Am] 2002;84:634-8.

8. Colby RS, Saul RA. Is Jaffe-Campanacci syndrome just a manifestation of neurofibromatosis type 1? Am J Med Genet A 2003;123:60-3.

9. Al-Rikabi AC, Ramaswamy JC, Bhat VV. Jaffe-Campanacci syndrome. Saudi Med J 2005;26:104-6.

10. Heck RS Jr. Benign bone tumors and nonneoplastic conditions simulating bone tumors. In: Canale ST, Beaty JH, editors. Campbell's operative orthopedics. Chapter 20, Philadelphia: Mosby -Elsevier; 2008. p. 855-81.

11. Tunay S, Kömürcü M, Erler K, Yildız C, AteşalpS, Başbozkurt M. Kemik tümörlerinde kapalı biyopsi uygulama sonuçlarımız. Eklem Hastalik Cerrahisi 2000;11:169-72. 